\title{
FRAMING COWORKING SPACES MARKETING STRATEGIES VIA SOCIAL MEDIA INDICES
}

\author{
Dimitrios Vagianos \\ Department of International and European Studies, University of Macedonia, Thessaloniki, Greece \\ e-mail: vagianos@uom.edu.gr
}

ORCID: 0000-0001-6932-1513

\section{Nikos Koutsoupias}

Department of International and European Studies, University of Macedonia, Thessaloniki, Greece e-mail: nk@uom.edu.gr

ORCID: 0000-0003-1664-5404

(C) 2021 Dimitrios Vagianos, Nikos Koutsoupias

This work is licensed under the Creative Commons Attribution-ShareAlike 4.0 International License. To view a copy of this license, visit http://creativecommons.org/licenses/by-sa/4.0/

Quote as: Vagianos, D., and Koutsoupias, N. (2021). Framing coworking spaces marketing strategies via social media indices. Econometrics. Ekonometria. Advances in Applied Data Analysis, 25(2).

DOI: 10.15611/eada.2021.2.01

JEL Classification: C38, L81

\begin{abstract}
In this paper an investigation of social media marketing techniques of Coworking spaces' type of business is performed, using datasets acquired using social media monitoring tools. Mediatoolkit has been used to scrap data deriving from the activity of the WeWork Instagram and Twitter accounts which were collected on a 24/7 basis from varying locations and in multiple languages in a fifteen-day time window. Indices related to sentiment, reach, influence, number of followers, retweets, likes, comments, and view scores formed the datasets that were examined by applying multiple correspondence analysis as well as the hierarchical clustering method. The aim of this paper was to explore the inherent properties of the multiple indices describing the general realm of social media marketing tools, and more specifically aspires to provide digital marketers with an alternative perspective of social media marketing strategies related to the emerging coworking spaces type of business. The authors identified three classes/segments of posts, whereas post polarity tends to relate to geographic location, regardless of the social media channel used for posting.
\end{abstract}

Keywords: multiple correspondence analysis, hierarchical clustering, social media marketing tools, coworking spaces.

\section{Introduction}

Data analytics can be applied in a variety of cognitive fields with marketing being traditionally among them. Advances of technology and digital media have led to the 
digital marketing era, opening new horizons for planning innovative marketing strategies. The World Wide Web has reshaped the business landscape in terms of market competitiveness (Tajvidi and Karami, 2017). Furthermore, the expansion of advanced electronic devices and social media have altered the relationship between brands and customers (Ghorbani, 2013). Today, consumers have unlimited access to information about brands, products, services and prices, as well as recommendations from other consumers. They are more empowered and sophisticated in the way they compare and purchase products or services (Chen, Fay, and Wang, 2011; Palmatier and Steinhoff, 2019). As many as $63 \%$ of customers expect customer service available on social media and $90 \%$ of customers have already used them to communicate with a brand or a company (We Are Social, 2019). Therefore, companies are being pressured to become digitally present on social media platforms and to tailor their marketing strategies (Tiago and Veríssimo, 2014). Under these circumstances, social media marketing is increasingly significant for business.

Currently, $90 \%$ of marketers recognize social media as a crucial component of marketing strategy (Tuten and Solomon, 2017). It is becoming common practice among organizations to adopt and exploit the properties and functionalities of social media. Effective and well-organized marketing activities on social media sites enable businesses to improve branding, CRM, research and sales promotion (Alves, Fernandes, and Raposo, 2016; Ashley and Tuten 2015; Naeem, 2019; Olanrewaju, Hossain, Whiteside, and Mercieca, 2020). With 3.48 billion users, social media represent a huge platform for businesses to promote products, services and access potential customers in the global audience (Olanrewaju et al., 2020; Sawicki, 2016). By marketing products and services on social media, the level of product awareness as well as customer online reviews are exponentially rising, and leading to electronic word-of-mouth advertising. Furthermore, social media platforms are becoming the primary venue for communication between companies and customers (Tuten and Solomon, 2017). They allow for more adaptive and interactive communication as well as for the development and maintenance of customer trust, relationships and loyalty (Lipiäinen, 2014; Tajvidi and Karami, 2017). Moreover, social media is a source of a vast amount of data obtainable by data mining, CRM applications and other techniques. Businesses have therefore an opportunity to conduct social media analysis and increase the effectiveness of their social media marketing strategy. Valuable customer information can be collected from social networks and subsequently measured, evaluated and interpreted. The transformation of data into social media metrics is conducted either by specialized organizations or the businesses themselves (Garrigos-Simon, Alcamí, and Ribera, 2012, pp. 1880-1890; Kaplan and Haenlein 2010, pp. 59-68; Misirlis and Vlachopoulou, 2018). By the successful utilization of customers' data as well as of their insights, the social media marketing of companies is based on a more personalized and meaningful form of communication (Lipiäinen, 2014). As such, businesses are able to satisfy individual customer needs, deliver a tailored customer experience and maintain brand loyalty 
beyond traditional marketing capabilities (Alves et al., 2016). Social media marketing is, therefore, a prerequisite for building online brand communities, driving leads and sales, improving business performance and sustaining their competitive position on the market.

Moreover, globalization and digital technologies have substantially transformed the world of work (Ivaldi, Pais, and Scaratti, 2018). Working has became possible at any place and time, and the stable employment paradigm is beginning to collapse (Spinuzzi, Bodrožić, Scaratti, and Ivaldi, 2019). Subsequently, remote work has spread and the number of self-employed workers, as well as freelancers, has increased (Weijs-Perrée, van de Koevering, Appel-Meulenbroek, and Arentze, 2019, pp. 534-548). The global workforce started to change, and economies are becoming more flexible, agile, entrepreneurial and innovative. Such market trends affected demand for office space as the need arose for a flexible working environment, other than traditional or private setting (Van de Koevering, 2017). Under these circumstances, coworking spaces provided a solution to the situation, and the proliferation of coworking spaces emerged at the onset of the structural changes in the labour market (Gandini, 2015; Merkel, 2015).

Coworking represents a new way of working expressed as individual work in a shared environment (Constantinescu and Devisch, 2018). Coworking space can be therefore understood as a shared workspace where professionals from different business backgrounds work alongside one another (Merkel, 2015; Weijs-Perrée et al., 2019). Thus it stimulates networking, collaboration and the development of a professionally heterogeneous community (Kubátová, 2014). Since its emergence in 2005 in San Francisco, the coworking sector has undergone rapid growth (Foertsch, 2019; Kubátová, 2014; Leclercq-Vandelannoitte and Isaac, 2016). The number of coworking spaces has globally risen from 600 in 2010 to 18700 open spaces in 2018, with 1650000 workers using coworking space (Statista, 2018a, 2018b). This rapidly growing phenomenon transformed the way people work and collaborate (Leclercq-Vandelannoitte and Isaac, 2016, pp. 3-9).

As pointed out above, data analytics can be applied in the field of social media marketing, exploiting the vast amount of data available in the numerous social media platforms towards shaping effective marketing techniques. Collaboration seems to be the common factor between social media applications and coworking spaces. This paper attempts to extract and analyse social media marketing data originating from the specific field of coworking spaces, and more specifically from the WeWork company's social media presence. The extracted datasets were analysed by applying multiple correspondence analysis and hierarchical clustering method in an effort to investigate whether these data analysis methods can support planning digital marketing strategies. 


\section{Literature review}

Data mining and the methods of Big Data studies have attracted a great deal of attention in the information industry in recent years, due to the wide availability of huge amounts of data in the social web and the urgent need for turning such data into useful knowledge (Gürsoy, Bulut, and Yigit, 2017). The potential of social media Big Data is colossal in marketing and with data being generated and collected in real-time, round the clock, seven days a week, the marketing industry is now able to see what people are buying, following or communicating about (Barutcu, 2017). The visualization of this kind of mined data has opened up new ways in evolving marketing decision models (Treboux et al., 2016). While social network analysis (Kefi, Indra, and Abdessalem, 2016) and content analysis can be one approach, the introduction of indexes that describe the social web's parameters have opened up new techniques of statistical research for a variety of fields. For example, Thoma et al. used a social media index containing four metrics to measure statistically the impact of emergency medicine and critical care websites (Thoma et al., 2015). Arora et al. introduced a mathematical model for social media index valuation involving technological, social, economic, and ethical dimensions in their attempt to create benchmarks signifying a company's share and commitment to social media (Arora, Arora, and Palvia, 2014). Zhou et al. also applied social media analysis to reveal collective behaviour based on data and indices retrieved from Twitter and Sina Weibo, the most popular microblogging services all over the world and in China, respectively (Zhou, Qian, and Ma, 2012). Bucko et al. used statistical methods to identify the factors that affect consumer purchasing behaviour by applying principal components analysis and factor analysis to their decision criteria (Bucko, Kakalejčík, and Ferencová, 2018). Advances in machine learning techniques raised the popularity of Sentiment Analysis which started to be used as a separate mature index in Social Media investigations generally (Iglesias and Moreno, 2019), as well as in quantitative and qualitative marketing research methods enriching the datasets under investigation (Rambocas and Gama, 2013). Markic et al. showed that sentiment analysis can be used to create marketing strategies and improve customer relations and customer service (Markic et al., 2016). Indices like reach, passion and strength have also been used in previous statistical analysis in marketing issues (Vagianos and Koutsoupias, 2017). In this kind of research, multiple correspondence analysis (MCA) is a common technique for identifying groupings, or market segmentation, in which groups of people with similar characteristics are considered together (Diana and Pronello, 2010). Furthermore, in recent decades cluster analysis has become a common tool for the marketing researchers, helping to create groupings of variables of the issue under investigation (Punj and Stewart, 1983).

In this paper, indices related to social media activity generated by the WeWork company that have to do with sentiment, reach, influence, number of followers, retweets, likes, comments and view scores, formed the datasets that have been 
investigated by applying multiple correspondence analysis (MCA) as well as hierarchical clustering $(\mathrm{HC})$. This approach has been used extensively in the research on marketing of services and products in numerous cases, such as the combined use of MCA and HC was employed by dos Santos et al. (2020) for the exploration of the insurance market. Similarly, Wen and Chen (2010) explored the competitive positions of international air travellers, Brida et al. (2014) studied sociodemographic and travel-related characteristics of cruises, whilst Diana and Pronello (2010) defined a set of different customer profiles regarding travellers' social status and characteristics and efficiency of transportation networks. Bejaei, Cliff, and Singh (2020) and Nicolosi, Fava, and Marcianò (2018) examined purchasing habits and preferences for fruit and fishery, respectively.

The procedure aimed to highlight social media Big Data from a new perspective which can help companies from this sector to effectively plan and adjust their marketing strategy.

\section{Dataset and variables}

In this paper, the dataset for analysis was retrieved using Mediatoolkit, an online media monitoring software that enables marketers and organizations to be notified about every mention of their company or product. It monitors over 10 million websites and 100 million social media profiles, helping brands to manage their online reputation. Whenever Mediatoolkit recognizes a mention, it immediately sends out a real-time alert that can be found in the email, online on the website or directly in the phone application (Mediatoolkit, 2019). This feature can be very helpful in the case of a negative mention because it can be put right without delay, not disrupting a brand's image to such an extent as if it had been left without notice for a longer period (FinancesOnline, 2019).

Table 1. Mentions of keywords and hashtags

\begin{tabular}{|l|c|}
\hline \multicolumn{1}{|c|}{ Monitored queries } & Mentions \\
\hline WeWork & 22275 \\
\hline \#wework & 5543 \\
\hline \#wearewework & 1477 \\
\hline \#dowhatyoulove+\#wework & 184 \\
\hline \#dogsofwework & 105 \\
\hline
\end{tabular}

Source: own elaboration.

The trial version of the platform was used in a 14-day window $\left(6^{\text {th }}-20^{\text {th }}\right.$ January 2019), in order to extract spreadsheets containing datasets as the results of mention queries. This version allowed for carrying out up to 100 queries, showing up to 50000 mentions, tracking keywords or phrases and monitoring or tracking on specific channels, such as Facebook, Twitter, Instagram, YouTube and general Websites. 
It also allowed for choosing only mentions of specific social media platforms with a specific language, location, authors or sentiment.

Mediatoolkit was used in order to investigate the social media activity performed by the WeWork Company. WeWork is a private American company that provides shared workspaces for entrepreneurs, start-ups and freelancers, as well as for small and big businesses. In just nine years of its existence, WeWork has created a global network of coworking spaces present in 660 locations, 115 cities and 27 countries. It manages $45 \mathrm{~m}$ square feet of office space globally where more than 400000 members can enjoy 100000 annual community events (Sullivan, 2018; WeWork, 2019). Therefore, in its early stages it could be viewed as a suitable example of a coworking spaces company with a proven ability to expand rapidly in a short period of time.

Eventually, five queries were executed over Instagram, Twitter and the web involving the following keywords or hashtags: \#dogsofwework, \#\#dowhatyoulove + \#wework, \#wearewework, \#wework and WeWork. The queries provided results relevant to mentions over time (Table 2), total impressions, positive-negative sentiment ratio and sentiment over time.

Specifically, they provided datasets involving the following variables: auto sentiment, reach, influence score, followers, like count, comment count, favorite count, view_count and retweet count. There were also metadata indicating details like the title length, the country of origin, the spoken language and whether there is an image or not in the posts. These variables were then classified into two main categories (Table 2): quantitative and qualitative.

Table 2. Variables' classification in Mediatoolkit's datasets

\begin{tabular}{|l|l|}
\hline \multicolumn{1}{|c|}{ Quantitative Vars } & \multicolumn{1}{c|}{ Qualitative Vars } \\
\hline TIT - Title Length (char length) & IMG - Has Image (boolean) \\
MEN - Mention (count) & TYP - Twittr/Instgr (T or I) \\
REA - Reach (index) & LAN - Language (ISO Code) \\
FOL - Followers (count) & SEN - Sentiment (index) \\
& INF - Influence (index) \\
\hline
\end{tabular}

Source: own elaboration.

The final selected data set was formed using MS Excel and R language base functions and is a complete table of 3967 rows and nine columns, since posts with no defined location, language and sentiment were excluded. The dataset with the variables described above provided the input for applying the MCA as well as the $\mathrm{HC}$ method described in the next paragraphs. 


\section{Methodology and results}

Recent surveys are increasingly collecting nonmetric data via categorical variables like opinion posts, difficult to analyse with the most frequently applied tools. Thus, as mentioned before, the methodology chosen for this data set exploration was a combination of multiple correspondence analysis in tandem with hierarchical clustering (Ward's metric) using the $\mathrm{R}$ package FactoMineR implementation (Le et al.). As with factor fnalysis and principal component analysis in parametric experiments, MCA reduces the dimensionality of results. Moschidis, Chatzipetrou, and Tsiotras (2018) provided detailed explanations of the combined use of MCA and HC. Further on, the mathematics on both methods is purposefully left out of this article. The statistical aspects of MCA can be found in the works of Benzecri (1992) and Clausen (1998), while the technicalities of HC can be found in Mirkin (2012).

The application of MCA assumes all examined variables are categorized, thus the TIT, MEN, REA and FOL values were initially transformed to categories based on the Q1, Q2-Q3, Q4 rule (Table 3).

Table 3. Initial Data Format (a) \& Final Input Table Format (b)

\begin{tabular}{|ccccccccc||ccccccccc|}
\hline TII & MEN & REA FOI & TMG & TYP & LAN & SEN & INF & TIT & MEN & REA & FOL & ING & TYP & LAN & SEN & INF \\
\hline 349 & 242 & 1 & 12 & 0 & twitter & EN & negative & 1 & T3 & M3 & R1 & F1 & IY & TT & EN & ne & IN1 \\
312 & 205 & 40 & 803 & 0 & twitter & EN & positive & 1 & T2 & M2 & R1 & F2 & IY & TT & EN & po & IN1 \\
292 & 232 & 114 & 1088 & 0 & twitter & EN & positive & 2 & T2 & M2 & R2 & F2 & IY & TT & EN & po & IN2 \\
256 & 208 & 192 & 2246 & 0 & twitter & EN & positive & 2 & T2 & M2 & R2 & F3 & IY & TT & EN & po & IN2 \\
350 & 243 & 720 & 1996 & 1 & instagram & EN & positive & 1 & T3 & M3 & R3 & F3 & IN & TI & EN & po & IN1 \\
350 & 244 & 330 & 996 & 1 & instagram & EN & positive & 1 & T3 & M3 & R2 & F2 & IN & TI & EN & po & IN1 \\
$:$ & $:$ & $:$ & $:$ & $:$ & $:$ & $:$ & $:$ & $:$ & $:$ & $:$ & $:$ & $:$ & $:$ & $:$ & $:$ & $:$ & $:$ \\
\hline
\end{tabular}

a)

b)

Source: own elaboration.

On the basis of the MCA output, the amount of inertia (total information revealed) in the examined data along the first axis is $19 \%$ and along the second axis is $13.6 \%$ (Figure 1). This is the first view of the examined data on a multi-variate basis, revealing the customer opinion main trends.

The main trends on the first axis relate to the posts bearing high values of Title Length (T3) and Mentions (M3), emerging from Instagram (TI), with no image present (IN) and low Influence (IN1), as opposed to Twitter posts (TT), with images (IN) and higher influence (IN2). The second axis is characterized by long and mid-sized Title Lengths (T3,T2) and high Mentions (M3), many followers (F3) on the one hand, and posts with small sized Title Lengths (T1) and few Mentions (M1), on the other. 
MCA-Var Categories axis 1 (19\% of tot. Inertia)

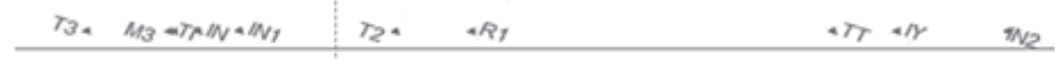

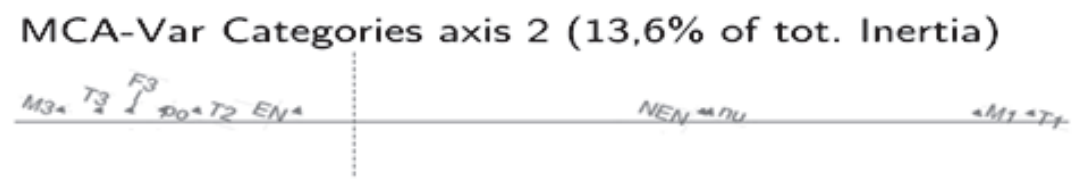

Fig. 1. Inertia along the first and second axis

Source: own elaboration.

The authors employed hierarchical clustering on MCA components (HCPC) with k-means consolidation on the coordinates obtained from the MCA, to assess the existence of clustered groups of posts (i.e. post profiles) in the examined population. The algorithm suggested three main groups of customer posts, as shown in Figure 2.

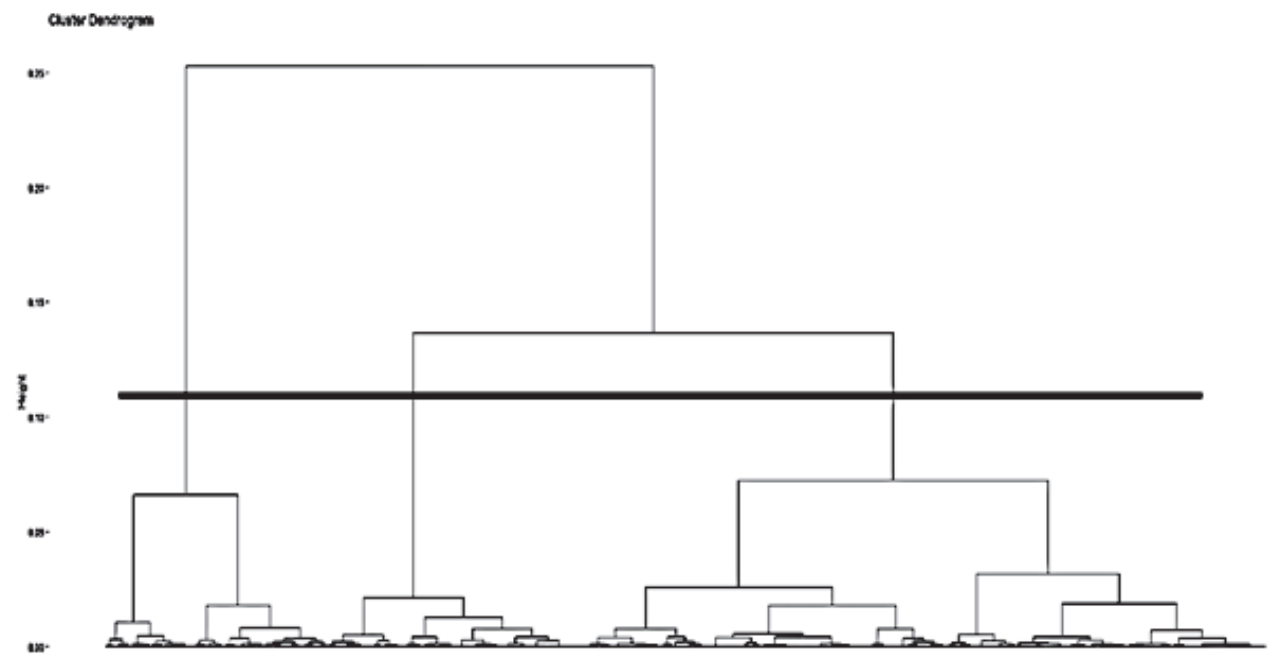

Fig. 2. Hierarchical clustering of posts

Source: own elaboration.

The Euclidean distance was calculated between individuals, and Ward's criterion was applied as the clustering method to minimize the within-cluster variance (Husson, Josse, and Pages, 2010). Furthermore, a chi-squared test ( $\chi 2$ test) was performed automatically via the implementation of MCA in the FcrtoMineR package to identify the variables that characterized the clusters. The chi-squared value is equal to (df). 


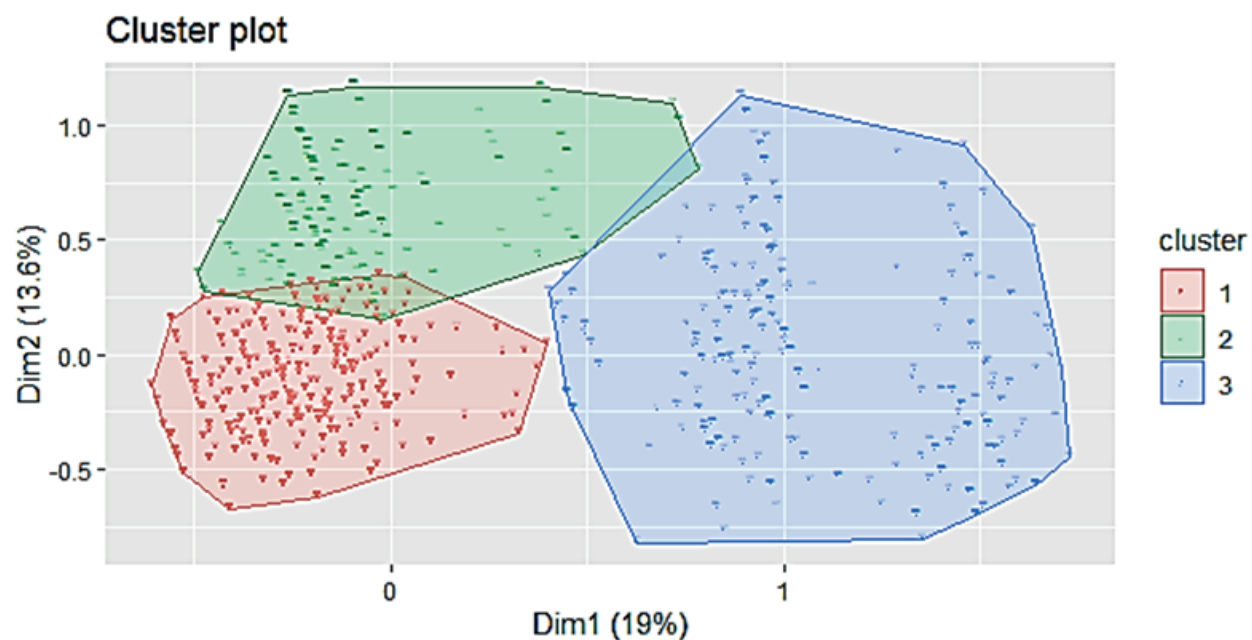

Fig. 3. Hierarchical clustering groups on the 1st factorial plane

Source: own elaboration.

The positioning of customer posts can also be depicted according to the clustering of post groups using the corresponding $\mathrm{R}$ tools, namely functions included in the factoextra package (Kassambara and Mundt, 2017). Each cluster is characterized by a distinct group of categories revealing inherent customer properties.

\section{Results and discussion}

The resulting clusters based on $\mathrm{HC}$ output have the following characteristics:

a) Cluster $1(n=1454)$ : represents neutral Instagram post mostly from Japan, Belgium, Italy Lithuania, China, India, Estonia, Turkey, Finland, Russia, Israel, Georgia, Slovakia, Portugal, Czechia, South Africa, and Hong Kong.

b) Cluster $2(n=1988)$ : corresponds to the most populated group, including posts on Instagram, YouTube and the Web. The countries present here are the US, the Netherlands, Australia, Saudi Arabia, Ethiopia, Ecuador, Armenia, Peru, Korea (the Republic of), Brazil, and Slovenia. All with mainly positive posts.

c) Cluster $3(n=525)$ : the smallest group includes mainly negative Instagram posts from Argentina, Sweden, Mexico, Denmark, Colombia, Jamaica, Ghana, Venezuela, Uruguay, and Somalia.

Thus, the employed multi-variable techniques clearly depict formations and clusters in the examined phenomenon, providing a full view. As shown earlier, in terms of service design and/or brand positioning/repositioning, the MCA axes (Figure 1) may initially provide key input to services marketers and brand managers. 


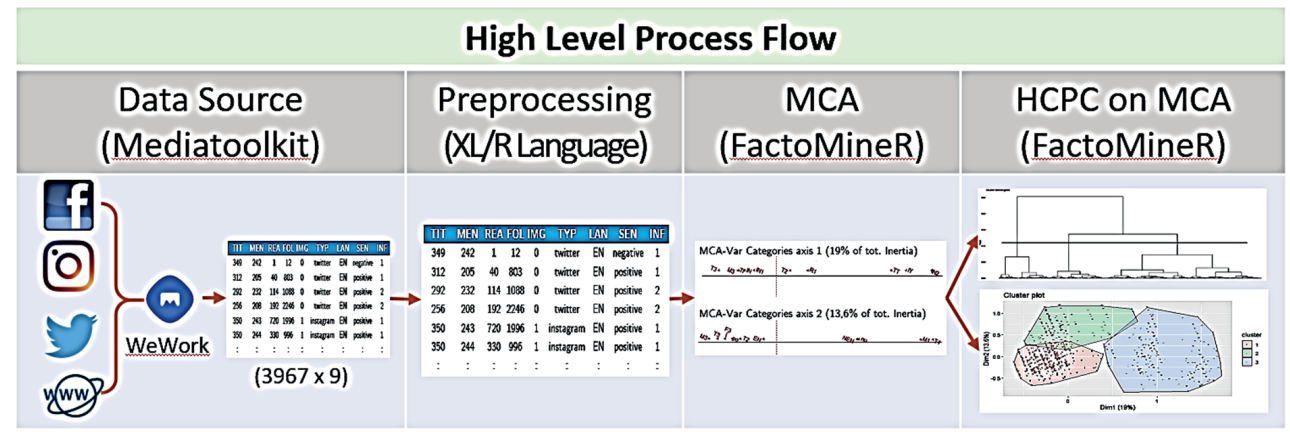

Fig. 4. High Level Process Flow

Source: own elaboration.

Additionally, HC may be used to assess which groups are thought to be closer to each other (Figure 3), in addition to the perceptual axes created by MCA. The general process flow of our methodological approach is depicted in Figure 4.

\section{Conclusion}

The combined use of MCA and HC defined three types of posts and revealed that, regardless of the social media channel used for posting, post polarity is mainly related to location. Each of these three groups of posts has distinct geographical characteristics, and online retailers may use this knowledge strategically to target their audiences more efficiently. Therefore, this study showed that the combination of these methods may serve as explorative preliminary research to investigate the interrelationship between posts and overall polarity on a per-country basis.

It must be noted that the selected time window of January 2019 provided pre-pandemic data that correspond to a time of normal prevailing circumstances. Recently, there has been a lot of debate about the impact of the pandemic on directions of various business models, and coworking spaces could be definitely among them. More recent time windows could provide biased results due to this fact. The validity of the results is further enhanced by the fact that the selected time window belongs to the period before the company's spectacular financial collapse in September 2019, which was due to a variety of reasons. It is more than evident that social media data retrieved over the months of the company's downfall would lead to misguided conclusions.

What exactly is the nature and depth of commitment reflected by the local coworking spaces industries at country level can be recommended for future research. Researchers adopting the proposed method (or other similar methods) should certainly take into account the limitations posed by the VPN services or chatbots over the validity of the sentiment analysis results. 


\section{References}

Alves, H., Fernandes, C., and Raposo, M. (2016). Social media marketing: A literature review and implications. Psychology and Marketing, 33, 1029-1038.

Arora, A., Arora, A. S., and Palvia, S. (2014). Social media index valuation: Impact of technological, social, economic and ethical dimensions. Journal of Promotion Management, 20, 328-344. doi: $10.1080 / 10496491.2014 .908803$

Ashley, C., and Tuten, T. (2015). Creative strategies in social media marketing: An exploratory study of branded social content and consumer engagement. Psychology and Marketing, 32, 15-27. doi: 10.1002/mar.20761

Barutcu, M. T. (2017). Big data analytics for marketing revolution. Journal of Media Critiques, 3(11). doi: $10.17349 / \mathrm{jmc} 117314$

Bejaei, M., Cliff, M. A., and Singh, A. (2020). Multiple correspondence and hierarchical cluster analyses for the profiling of fresh apple customers using data from two marketplaces. Foods, 9(7), 873. doi: $10.3390 /$ foods 9070873

Benzecri, J. P. (1992). Correspondence analysis handbook. New York: Marcel Dekker.

Brida, J. G., Scuderi, R., and Seijas, M. N. (2014). Segmenting cruise passengers visiting Uruguay: A factor-cluster analysis. International Journal of Tourism Research, 16(3), 209-222. doi: 10.1002/ jtr. 1916

Bucko, J., Kakalejčík, L., and Ferencová, M. (2018). Online shopping: Factors that affect consumer purchasing behavior. Cogent Business \& Management, 5(1). doi: 10.1080/23311975.2018.1535751

Chen, Y., Fay, S., and Wang, Q. (2011). The role of marketing in social media: How online consumer reviews evolve. Journal of Interactive Marketing, 25, 85-94. doi: 10.1016/j.intmar.2011.01.003

Clausen, S. E. (1998). Applied correspondence analysis: An introduction. Vol. 121. Sage.

Constantinescu, T., and Devisch, O. (2018). Portraits of work: Mapping emerging coworking dynamics. Information Communication and Society, 21, 1263-1278. doi: 10.1080/1369118X.2018.1459775

Desarbo, W. S., Hausman, R. E., and Kulkitz, J. M. (2007). Restricted principal components analysis for marketing research. Journal of Modelling in Management, 2(3). doi: 10.1108/17465660710834471

Diana, M., and Pronello, C. (2010). Traveler segmentation strategy with nominal variables through correspondence analysis. Transport Policy, 17(3), 183-190.

dos Santos, J. R. R., Dias, C. M., and Chiavegatto Filho, A. (2020). Machine learning and national health data to improve evidence: Finding segmentation in individuals without private insurance. Health Policy and Technology. doi: 10.1016/j.hlpt.2020.11.002

Foertsch, C. (2019). 2019 State of Coworking: Over 2 million coworking space members expected. Retrieved from https://www.deskmag.com/en/coworking-news/2019-state-of-coworking-spaces2-million-members-growth-crisis-market-report-survey-study

Gandini, A. (2015). The rise of coworking spaces: A literature review. Ephemera: Theory \& Politics in Organization, 15, pp. 193-205.

Garrigos-Simon, F. J., Alcamí, R. L., and Ribera, T. B. (2012). Social networks and Web 3.0: Their impact on the management and marketing of organizations. Management Decision, 50. doi: $10.1108 / 00251741211279657$

Ghorbani, A. (2013). Marketing in the cyber era: Strategies and emerging trends. IGI Global. doi: 10.4018/978-1-4666-4864-7

Gürsoy, U. T., Bulut, D., and Yigit, C. (2017). Social media mining and sentiment analysis for brand management. Global Journal of Emerging Trends in e-Business, Marketing and Consumer Psychology (GJETeMCP), 3(1).

Husson, F., Josse, J., and Pages, J. (2010). Principal component methods-hierarchical clustering-partitional clustering: Why would we need to choose for visualizing data. Semantic Scholar. Retrie- 
ved October 6, 2020 from https://www.semanticscholar.org/paper/Principal-component-methodshierarchical-clustering-Josse/04335d99d840ac3370f5aeb262828cf127d3ff1c

Iglesias, C. A., and Moreno, A. (2019). Sentiment analysis for social media. Applied Sciences, 9(23), 5037, MDPI.

Ivaldi, S., Pais, I., Scaratti, G. (2018). Coworking(s) in the plural: Coworking spaces and new ways of managing. The New Normal of Working Lives. Springer International Publishing, 219-241. doi: 10.1007/978-3-319-66038-7_11

Kaplan, A. M., and Haenlein, M. (2010). Users of the world, unite! The challenges and opportunities of social media. Business Horizons, 53, 59-68. doi: 10.1016/j.bushor.2009.09.003

Kassambara, A., and Mundt, F. (2017). Package "factoextra" for $R$ : Extract and visualize the results of multivariate data analyses. Retrieved October 6, 2020 from https://CRAN.Rproject.org/package $=$ factoextra/

Kefi, H., Indra, S., and Abdessalem, T. (2016). Social media marketing analytics: A multicultural approach applied to the beauty\& cosmetic sector (Pacific Asia Conference on Information Systems (PACIS) proceedings, Paper 176).

Kubátová, J. (2014). The cause and impact of the development of coworking in the current knowledge economy (Proceedings of the European Conference on Knowledge Management, ECKM 2), 571-577 .

Leclercq-Vandelannoitte, A., and Isaac, H. (2016). The new office: How coworking changes the work concept. Journal of Business Strategy, 37, 3-9. doi: 10.1108/JBS-10-2015-0105

Lipiäinen, H. (2014). Digitization of the communication and its implications for marketing. Jyväskylä Studies in Business and Economics, 152, University of Jyväskylä.

Markic, B., Sanja, B., and Bevanda, A. (2016). Sentiment analysis of social networks as a challenge to the digital marketing. Ekonomski Vjesnik/Econviews-Review of Contemporary Business, Entrepreneurship and Economic Issues, XXIX(1/2016), 95-107.

Merkel, J. (2015). Coworking in the city. Ephemera: Theory \& Politics in Organization, 15, 121-139.

Mirkin, B. (2012). Clustering: A data recovery approach. CRC Press.

Misirlis, N., and Vlachopoulou, M. (2018). Social media metrics and analytics in marketing - S3M: A mapping literature review. International Journal of Information Management, 38(1), doi: 10.1016/j.ijinfomgt.2017.10.005

Moschidis, O., Chatzipetrou, E., and Tsiotras, G. (2018). Quality costing and quality management maturity in Greece: An exploratory multi-dimensional data analysis. International Journal of Productivity and Performance Management, 67(1), 171-191. doi: 10.1108/IJPPM-08-2016-0152

Naeem, M. (2019). Do social networking platforms promote service quality and purchase intention of customers of service-providing organizations?, Journal of Management Development, 38, 561-581. doi: 10.1108/jmd-11-2018-0327

Nicolosi, A., Fava, N., and Marcianò, C. (2018). Consumers' preferences for local fish products in Catalonia, Calabria and Sicily. (In International Symposium on New Metropolitan Perspectives, 103-112). Cham: Springer.

Olanrewaju, A. S. T., Hossain, M. A., Whiteside, N., and Mercieca, P. (2020). Social media and entrepreneurship research: A literature review. International Journal of Information Management, 50, 90-110. doi: 10.1016/j.ijinfomgt.2019.05.011

Palmatier, R. W., and Steinhoff, L. (2019). Relationship marketing in the digital age. Routledge.

Punj, G., and Steward, D. W. (1983). Cluster analysis in marketing research: Review and suggestions for application. Journal of Marketing Research, XX, May.

Rambocas, M., and Gama, J. (2013). Marketing research: The role of sentiment analysis. (FEP Working Papers, No. 489), April.

Sawicki, A. (2016). Digital marketing. World Scientific News, 48, 82-88. 
Sullivan, M. (2018). Survey finds that collaboration is key to employee happiness. WeWork ideas, Retrieved September 14, 2019 from https://www.wework.com/ideas/survey-finds-that-collaborationis-key-to-employee-happiness

Spinuzzi, C., Bodrožić, Z., Scaratti, G., and Ivaldi, S. (2019). coworking is about community: But what is community in coworking?, Journal of Business and Technical Communication, 33, 112-140. doi: $10.1177 / 1050651918816357$

Statista. (2018a). Number of coworking spaces worldwide 2018. Retrieved September 14, 2019 from https:/www.statista.com/statistics/554273/number-of-coworking-spaces-worldwide/

Statista. (2018b). Coworking spaces: Number of members worldwide 2018. Retrieved September 14, 2019 from https:/www.statista.com/statistics/554315/number-of-people-working-in-coworkingspaces-worldwide/

Tajvidi, R., and Karami, A. (2017). The effect of social media on firm performance. Computers in Human Behavior. doi: 10.1016/j.chb.2017.09.026

Thoma, B., Sanders, J., Lin, M., Paterson, Q. S., Steeg, J., and Chan T. M. (2015). The Social Media Index: Measuring the impact of emergency medicine and critical care websites. The Western Journal of Emergency Medicine, March 2015. doi: 10.5811/westjem.2015.1.24860

Tiago, M. T. P. M. B., and Veríssimo, J. M. C. (2014). Digital marketing and social media: Why bother?, Business Horizons, 57, 703-708. doi: 10.1016/j.bushor.2014.07.002

Treboux, J., Cretton, F., Genoud, D., Calvé, A., Evéquoz, F., Jarac, A. J., and Larpin, B. (2016). SoDA - Social Media Data Analysis (1st Swiss Text Analytics Conference), Whinterthur, Switzerland, June.

Tuten, T. L., and Solomon, M. R. (2017). Social media marketing. Sage Publishing.

Vagianos, D. and Koutsoupias, N. (2019). Twitter \& instagram indices analysis as a tool to frame coworking spaces digital marketing strategy (16th International Federation of Classification Societies) 26-29 August 2019, Thessaloniki, Greece. doi: 10.13140/RG.2.2.15566.61763

Van de Koevering, J. G. C. (2017). The preferred characteristics of coworking spaces the relation between user characteristics and preferred coworking space characteristics: An attribute based stated choice experiment. Student thesis (Master), Eindhoven University of Technology.

Weijs-Perrée, M., van de Koevering, J., Appel-Meulenbroek, R., and Arentze, T. (2019). Analysing user preferences for co-working space characteristics. Building Research and Information, 47, 534-548. doi: 10.1080/09613218.2018.1463750

Wen, C. H., and Chen, W. Y. (2010). Airlines' competitive positioning using multiple correspondence cluster analysis (12th WCTR, July), 11-15.

Zhou, A., Qian, A., and Ma, H. (2012). Social media data analysis for revealing collective behaviors (KDD '12: Proceedings of the 18th ACM SIGKDD international conference on knowledge discovery and data mining, August 2012). doi: 10.1145/2339530.2339746

\section{Websites}

FinancesOnline. (2019). Retrieved from https://crm.financesonline.com/

Mediatoolkit. (2019). Retrieved from https://www.mediatoolkit.com/

WeWork. (2019). Retrieved from https://www.wework.com

We Are Social. (2019). Retrieved from https://wearesocial.com/global-digital-report-2019 


\section{OKREŚLENIE ZAKRESU STRATEGII MARKETINGOWYCH PRZESTRZENI COWORKINGOWYCH NA PODSTAWIE WSKAŹNIKÓW MEDIÓW SPOŁECZNOŚCIOWYCH}

Streszczenie: W artykule zaprezentowano wyniki badania technik marketingu społecznościowego w biznesie typu coworking przy użyciu zbiorów danych uzyskanych za pomocą narzędzi do monitorowania mediów społecznościowych. Do wycinania danych pochodzących z aktywności kont firmy WeWork na Instagramie i Twitterze wykorzystano Mediatoolkit. Dane były gromadzone 24 godziny na dobę, 7 dni w tygodniu, z różnych lokalizacji i w wielu językach, w piętnastodniowym przedziale czasowym. Wskaźniki związane z sentymentem, zasięgiem, wpływem, liczbą obserwujących, retweetami, polubieniami, komentarzami i wynikami wyświetleń utworzyły zbiory danych, które zostały zbadane za pomocą analizy korespondencji wielu zmiennych, a także metody hierarchicznego grupowania. Celem artykułu jest zbadanie nieodłącznych właściwości wielu indeksów opisujących ogólną dziedzinę narzędzi marketingu wykorzystywanych w social mediach. Autorzy pragną udostępnić marketerom cyfrowym alternatywną perspektywę prowadzenia strategii marketingowych w obszarze mediów społecznościowych związanych z nowatorskimi przedsięwzięciami dotyczącymi przestrzeni coworkingowych. Zidentyfikowano trzy kategorie/segmenty postów, przy czym polaryzacja postów zwykle odnosi się do lokalizacji geograficznej, niezależnie od kanału mediów społecznościowych używanego do publikowania.

Słowa kluczowe: analiza korespondencji wielu zmiennych, klasyfikacja hierarchiczna, narzędzia marketingu w mediach społecznościowych, przestrzenie coworkingowe. 